\title{
The problems of human embryos genome editing from the position of Christian denominations
}

\author{
E.E. Gribkov ${ }^{1}$, T.P. Minchenko² \\ astratys@gmail.com |mtp70@mail.ru \\ ${ }^{1}$ National Research Tomsk State University \\ ${ }^{2}$ Tomsk State Pedagogical University
}

\begin{abstract}
Modern biomedical technologies pose bioethical dilemmas foe humanity. On the one hand, medical advances can make life much easier for people, but, on the other hand, the problem of interference in human nature actualizes the most fundamental questions regarding his ontology, the boundaries of permissible transformations, the responsibility of a scientist and a specialist who applies the latest technologies, for remote and unpredictable consequences, due to the integrity and interconnectedness of various aspects of human nature. In the scientific literature, there is a lot of information about the attitude of various denominations to genetic manipulation. This paper presents the experience of generalizing and systematizing the attitude of the main Christian confessions to the problem of editing the human embryo genome. The assessment of modern biomedical technologies from the standpoint of the Christian worldview differs, on the one hand, in the moral depth due to spiritual experience in relation to the higher divine principle, and, on the other hand, if we bear in mind the specificity of the Orthodox, Catholic and Protestant views on the problem of genetic manipulations, it is diversity interpretations in connection with historically arisen and existing to this day confessional and doctrinal differences.
\end{abstract}

Key words: biomedicine, bioethics, human, embryo, genetic manipulation, Roman Catholic Church, Russian Orthodox Church, Protestantism.

\section{Introduction}

Intensive development of biomedicine in the XX XXI centuries generates fundamentally new ethical problems in the scientific community and society as a whole. Various social groups form their own vision of current issues of bioethics. In particular, the problems of genome editing in the modern world have an ambiguous interpretation from the standpoint of scientific, religious, political, economic, legal and other approaches. The purpose of this work is to study and compare the attitude of various Christian denominations to the problem of genome editing of the human embryo.

XXI century became revolutionary for biomedical sciences, completely new methods and technologies were developed in bioengineering, synthetic biology, molecular genetics. Among the new technology's potential applications are the treatment of hereditary diseases (hemophilia, beta-thalassemia, and muscular dystrophy), cancer therapy and viral infections therapy, including the human immunodeficiency virus (HIV). However, there are also more exotic potential uses. For example, combating multifactorial diseases (diabetes, schizophrenia, etc.) or editing embryos during artificial insemination to select quality characteristics in children. It is here that many ethical issues arise that have begun to be discussed, but have not yet received a consensus solution from the international community. When can and when can not genome editing be used? So far, in the absence of a unified position among humanity, each of the countries is solving this problem in its own way, based on the prevailing socio-cultural characteristics.

To solve the bioethical problem of gene editing, it is necessary to determine the problem of human essence, because the embryo does not have a generally accepted status in the world. Due to the complex definition, a multilevel analysis of the problem is required. For human society, one of the most important spheres of knowledge is religion, it forms everyday ethics. The religious vision is ambiguous, due to the divergence in theological issues of ideas about the status of the embryo.

Consequently, the problem of the admissibility of editing the genes of the human embryo from the standpoint of the main Christian confessions in the work must be investigated in an inextricable connection with the concept of human ontology.

\section{Position of Catholicism}

The most widespread, developed and influential is the position on this issue of the largest Christian confession the Roman Catholic Church (RCC), with more than a billion followers. This position is dominant in Europe and it is well represented in the scientific communities of the world as a whole.

Here are the most important documents that determine the position of the RCC in the field of genetic manipulations, as well as the qualitative stages in the development of this position in connection with significant progress in medical science and genetics, which gave the main impetus for bioethics development:

- Speech of Pope PIUS XII «To participants in the Primum Symposium Internationale Geneticae Medicae» (September 7, 1953) [1];

- Address of John Paul II. To members of the Pontifical Academy of Sciences. Saturday, 23 October 1982 [2];

- Charter of the Rights of the Family, October 22, 1983, article 4C [3];

- Address of His Holiness Pope John Paul II at The Conclusion of the thirty-fifth General Assembly of the World Medical Association, Saturday, 29 October 1983 [4];

- Congregation for the doctrine of the faith. Instruction on respect for human life in its origin and on the dignity of procreation. Replies to certain questions of the day [5];

- Ioannes Paulus II Evangelium Vitae. To the Bishops, Priests and Deacons, Men and Women, religious lay, 
Faithful and all People of Good Will on the Value and Inviolability of Human Life. 25 March 1995 [6];

- Concluding Document of IV Plenary Assembly of the Pontifical Academy for Life «The Human Genome: Human Personhood and Future Society», February 23 - 251998 [7];

- Congregation for the Doctrine of the Faith. Instruction Dignitas Personae on certain bioethical questions. 8 September 2008 [8];

- Charter for Health Care Workers. Pontifical Council for Pastoral Assistance to Health Care Workers [9].

An important aspect of the institutionalization of biomedical ethics in Catholicism is associated with the founding in 1985 by Pope John Paul II of the Pontifical Commission (later renamed the Pontifical Council of Pastoral Assistance to Medical Workers). and in 1994 the Pontifical Academy for Life, which still plays a key role in the development and decision-making in the field of bioethics [10].

As we know, the organizational feature of the RCC is clear centralization, the messages of the Pope are the most authoritative for the entire Church. For the RCC, the development of the scientific and technological process is a blessing, which is confirmed by Pope Francis' reference to the words of Pope John Paul II, who emphasized the blessings of scientific and technological progress, "showing how noble is the vocation of man to responsibly participate in the creative action of God," but at the same time reminded that "no intervention in the sphere of the ecosystem can overlook its consequences in other spheres." He argued that the Church values the contribution "to the study and application of molecular biology, complemented by other disciplines such as genetics and its technological applications in agriculture and industry" [11]. Also in this encyclical, a positive attitude of the church was expressed to various kinds of research and scientific discoveries for the world of animals and plants, but categorically negative in relation to experiments on humans.

The Catholic Church raises the question of the status (or nature) of human embryos, which it considers originally human: "the embryo is originally human and should be treated as 'as if it was a person', with the ensuing human rights and dignity. The embryo is already a person, and does not become one: from the moment of gamete fusion and up to birth (and further), it represents one and the same human being, autonomously and continuously developing" [12, p.100-101].

The address of John Paul II to the participants of the 35th General Assembly of the World Medical Association contains the quintessence of the official position of the RCC in understanding the essence of man and the attitude to genetic manipulation in general:

1. Genetic interventions should not interfere with the natural origin of human life. The continuation of the human race is associated not only with a biological union, but also with a spiritual union between parents, who are united by marriage;

2. It is necessary to consistently respect the fundamental human dignity and, in general, biological nature, which underlies rights and freedoms;
3. It is necessary to avoid manipulations that tend to alter the genetic heritage and create groups of excellent people, at the risk of leading to new cases of isolation in society;

4. The fundamental relationship that inspires genetic research and experiments should not be based on a racist or materialist mentality that seeks to improve human well-being, but in fact, it is reductionist. Human dignity extends far beyond just its biological component;

5. Genetic manipulations become arbitrary and unfair if life is reduced to an object, if we forget that researchers are dealing with a human subject, gifted with reason and freedom, worthy of respect despite any restrictions. One cannot perceive a person from the point of view of criteria that are not based on the integral reality of the human person, at the risk of limiting his dignity. In such cases, they often sacrifice a person's individual good for the whim of others, thereby depriving the person of autonomy;

6. Whatever the scientific and technological progress, it must maintain the greatest respect for the moral values that protect the dignity of the human person. In the list of medical values, life is the highest and most fundamental good of a person, so we must follow the principle "first resist everything harmful, and then proceed to the search and achievement of good [4].

The use of embryos for genetic manipulation, for commercial purposes, "absolutely contradicts their dignity" [12, p.102], "the use of embryos in scientific research or experiments designed to meet the needs of society is incompatible with the concept of human dignity" $[13, \mathrm{I}, 4]$.

Analyzing the messages of the Popes, the rationale of Catholic scientists [see e.g.: 14], Social doctrine of the RCC [15], we can conclude that the priority for the RCC is the protection of the dignity of the personality of each individual from the beginning of its existence. RCC upholds the principle of inviolability: "It is impermissible to do evil in order for good to come from it" [16]. This principle prohibits experiments on human embryos, even if they are theoretically aimed at curing diseases and improving the health of many in the future.

The RCC calls for the use of other research methods, in particular the use of animals for experiments. Although methodologically it will be more difficult, nevertheless, the results of such studies will be more ethical and will not bring much more to humanity.

\section{Protestant position}

As for the numerous areas of Protestantism, the second largest denomination of Christianity by the number of followers, a wide variety of positions in relation to the investigating problem connected with the specifics of churches arrangement and the peculiarities of dogma.

Most local churches are autonomous and do not share common social positions. Thus, the majority of Russian Protestant churches are on the brink of "survival", with almost complete absence of any serious spiritual 
education. Therefore, the issues of biomedical ethics, which require some preparation, both in the fields of medicine and biology, and in the fields of philosophy and theological anthropology, are not raised in the proper form. There is a "Social position of the Protestant churches in Russia" [17], which superficially describes all the problems faced by the Russian Protestant community.

This is not the case for Western Protestant churches. The level of theology, the percentage of educated clergy and flock is much higher, which affects the immediate response to incoming ethical problems. The Community of Protestant Churches in Europe (CPCE) can rightfully be considered one of the most authoritative opinions of the Protestant world in the field of bioethics. In 2017, a guide to the ethics of reproductive medicine was published from the CPCE "Before I formed you in the womb..." [18], which examines the status of the embryo and possible manipulations with it. Since CPCE has a large number of churches with different theologies, their opinions cannot be uniform, so this guide shows a spectrum of opinions.

With regard to issues of bioethics, somewhat simplifying the overall complex picture, we can distinguish two poles of opinions emanating from different ontological understanding. In the idea of the nature of being, two extreme positions are revealed:

1. An imperfect sinful world with sinful creatures. Man in it is a co-creator, making decisions and using scientific methods to improve carnal imperfection. This concept considers technological progress as an opportunity to free one from the shackles of sinful flesh, an opportunity to improve the human race.

2. An ideal inviolable world created by the Creator in all its beauty and completeness. In this world, man is only a perishable creation that does not have the right to touch the world. This concept prohibits all possible research in the field of biomedicine, only the Creator is the infallible author, encroaching on the creation, we only aggravate the situation [18, p. 44]. Of course, there is a whole palette of views gradually flowing from conventional "conservatism" to "liberalism".

The main problem determining the decision on the admissibility of intervention in divine creation is the status of the embryo. In this regard, Protestant trends are also represented by a spectrum of views between two extreme positions:

1. Is the embryo a "human beings" and a "person"? The person is a member of the human community, actively contacts and benefits this society. A number of criteria indicates personality: rationality, selfawareness, the ability to interact, the ability to abstract thinking. In this concept, a person becomes a person gradually, i.e. has several stages of development. The embryo is at the very first stage of human development and does not have personality characteristics. Therefore, embryos do not have exactly the same moral rights as a person-personality $[18$, p. 50$]$.

2. The embryo is a person only because it is an individual. The adherents of this concept rely on the Aristotelian-Thomistic metaphysic: what makes a human person is the presence of a human soul, which gives the matter of the body a distinctively human form [18, c. 51]. The presence of the soul in the body already makes a personality out of the embryo, at the earliest stage of its development. The human embryo is a human being with human dignity from the moment of fertilization. For instance, American Lutheran Gilbert Meilaender argues that "the human embryo is fully deserving of our moral respect and that such respect is incompatible with its deliberate destruction in research [19, C. 290].

Protestant attitude to the problem is very multifaceted; a different vision allows to study various aspects of bioethics problems from different positions. There can be no single correct opinion, but the churches are trying to find an agreed path that will lead to the solution of emerging ethical issues in society in relation to acute biomedical dilemmas.

\section{The position of Orthodoxy}

The Orthodox Church unites a community of autocephalous and autonomous Churches that are administratively independent from each other and have Eucharistic communion with each other. Orthodoxy is the predominant confession in Russia, in parts of the Balkan countries (Greece, Serbia, Bulgaria, Romania, North Macedonia, Montenegro), in Ukraine, Belarus, Moldova, Georgia and Cyprus) [20].

Among Autocephalous Churches, there is no unequivocal consensus about editing the human embryo genome. The most widespread and influential position is the position of the Russian Orthodox Church, which is held by a significant part of the population of Russia [21]. On the basis of religious belief, a view on the moral and ethical problems of biomedicine is formed.

The Russian Orthodox Church (ROC) is very cautious about the use of new medico-genetic techniques. The main document "Bases of the Social Concept of the Russian Orthodox Church" describes the attitude of the church to the new problems of bioethics. The Church supports the desire of physicians to cure hereditary diseases, however, the purpose of genetic intervention should not be an artificial "improvement" of the human race and intrusion into God's plan for man [22]. The Church-Public Council on Biomedical Ethics of the Russian Orthodox Church, without denying the importance of medical genetics, expressed concern about the ethical side of manipulation of living embryos, which may have the following negative consequences:

1. Possible errors of inaccurate editing of the genome;

2. The impossibility of predicting the negative consequences of genetic editing in a number of generations of carriers of the altered genes;

3. The risk of the formation in a market economy of an attitude towards designer embryos, and then towards to child as a product;

4. Development of new forms of eugenics, contributing to the devaluation of human dignity and the loss of the equal value of all people;

5. The attitude towards human embryos as a consumable material for experiments, despite the fact that in 
relation to them it is necessary to apply the same norms and standards as to experiments on humans [23, p. 123].

However, not all Orthodox churches are strongly opposed to research. Thus, the current members of the ecumenical movement The Conference of European Churches (CEC), members of the Church and Society Commission, are: Albanian, Cypriot, Czech, Slovak, Estonian, Finnish, Greek (Greek), Polish, Romanian and Serbian Orthodox churches. They describe their vision of this problem in their thematic reference book "Moral and Ethical Issues in Human Genome Editing" [24].

As a result of considering this problem by ecumenical movement members, the following conclusions were made: Genome editing is seen as the next historical step in our ability to analyze and change the genetics of plants and animals, including ourselves. Hasty decisions and conclusions can lead us to fall, and the story in the Garden of Eden is a biblical example. However, in equal measure, history shows tremendous advances in medicine that come from the use of our intellect and imagination. New developments in genome editing will require us to rethink how we can balance the hope of a happy future with the fear of a dire future. Therefore, there is an urgent need for clear guidelines on the problem that has arisen, drawn up in an interdisciplinary dialogue between scientists, bioethics, theologians and lawyers.

\section{Viewpoints of some other Christian denominations}

Spiritual Christianity (Russian proto-Protestantism) is one of the specific branches of Christianity that broke away from the Russian Orthodox Church in the late 17th - early 18th centuries. One of the most common representatives of this trend is the Molokans. A collective council manages the community. In essence, each community is an autonomous and full-fledged church in its positions. The Presbyter of the community is the face of such a community, and it should be noted that this is a spiritual form of ministry that is in no way identified with the hierarchical structure of government. Presbyter, Molokan thinker Viktor Vasilyevich Tikunov [25], when asked about the possibility of using the techniques of genetic editing of human embryos, reflects as follows: "Has science achieved an understanding of the essence of life? To invade what is not yet fully understood and change what is not comprehended is the way to the abyss, the depth of which is also unknown" [26], and gives an unequivocal answer - no, to any manipulations associated with genetic engineering.

One of the most ancient branches in Christianity is Anti-Trinitarianism. Anti-trinitarian trends in Christianity have never had a single doctrine (as, indeed, trinitarian ones), they are united only by the rejection of the Trinitarian dogma.

The largest denomination of anti-Trinitarian Christian restorers is The Church of Jesus Christ of Latter-day Saints (TSIHSPD). For TSIHSPD, a special vision of human life is noteworthy: a person begins his existence with a spiritual form, then this spirit infiltrates human matter, however, no direct revelation has been received about when exactly it enters the body [27].

The Church teaches its flock to treat life and their bodies with due respect. Parishioners are blessed to use the latest medical techniques to heal their bodies. At the same time, the church does not recommend turning to medical and health-improving practices that are questionable from the point of view of ethics or legislation. However, he advises to contact competent and practicing professionals, whose activities are licensed at the state level.

The Church does not oppose the use of new methods in medicine, but it sets moral barriers that are not recommended to go beyond. The church does not have the right to prohibit church members from using methods that go beyond the scope of morality, while all responsibility falls on the conscience of the spouses, no church sanctions are applied in this case [27, p. 21.4 21.4.7].

The second largest trend in anti-Trinitarianism is Christian restorers premillennialists - Jehovah's Witnesses. Christians of this denomination perceive the beginning of human life from the moment of the fusion of two gametes [28, pp. 1-11]. Accordingly, any manipulations with the embryo are perceived as with a person. From the point of view of the church, new medical techniques to cure a person are acceptable. But the experimental part of embryo manipulation raises moral and ethical questions. Scientists in experiments with embryos are too free to deal with human life, which is sacred. Jehovah's Witnesses argue that, despite the great progress made by people in the field of science and technology, it is impossible to protect oneself - and even more so others - from old age, disease and, ultimately, death [29, pp. 1-10], that talks about the admissibility of new technologies, but lack of faith in their effectiveness.

Oriental Orthodox churches of the East are six archaic churches that do not recognize the Chalcedonian and all subsequent cathedrals, they are designated as Miathisite or non-Chalcedonian churches.

The Syrian Orthodox Church is one of six nonChalcedonian churches. Human life in the teachings of the church is seen as the union of soul and body. A feature of the ontological understanding of the Syrian Church is the acceptance of Aristotle's interpretation: the soul enters the male fetus when he is forty days old, and into the female fetus when he is ninety days old [30, pp. 583bpp. 3-23].

Since human life is sacred, but until a certain period of time the fetus is not human, the church does not prevent medical manipulation. It should be noted that the church has a positive view of the institution of "family planning", which primarily considers a happy family and healthy children.

A broad understanding of medicine can be traced throughout the history of Syrian Christianity, having a significant impact on many aspects of its intellectual culture, as well as daily life. Since ancient times, Syrian Christianity has been interested in teaching not only religious culture, but also general sciences such as medicine, astronomy, philosophy, history, language and others. Thus, religion is not limited to the salvation of the 
soul, but also extends to the care of the body, because it cares about the person as a whole [31].

It is worth noting the historical process of the adoption by the Syrian Church of Aristotelian philosophy and Galenian medicine [32]. Keeping traditions alive, the Syrian Church has a positive attitude towards the development of medical science, including research in the field of genetic engineering, for editing human embryos.

\section{Conclusions}

Finally, the author concludes that the position of the main Christian denominations is ambiguous on the problem of editing the human genome, the different degree of elaboration of this problem in theological works and documents of various Christian movements.

Thus, the largest in terms of the number of followers and the most influential of the Christian denominations, the centralized RCC, prohibits experiments on human embryos, even if they are theoretically aimed at curing diseases.

Numerous Protestant churches represent a wide range of opinions between two extreme positions: from the permissibility of using scientific methods and genetic manipulation to improve human fleshly imperfection to the prohibition of all possible research in the field of biomedicine.

Autocephalous Orthodox churches, as well as large movements of Christianity that are not included in the main 3 confessions, represent various positions - from a categorical prohibition on any manipulations related to genetic engineering to the admissibility of the use of new technologies after scientists, theologians, ethicists and lawyers have developed clear principles that take into account the unity of the spiritual, mental and bodily aspects of a person.

\section{References}

[1] To participants in the Primum Symposium Internationale Geneticae Medicae (September 7, 1953). http://w2.vatican.va/content/piusxii/en/speeches/1953.index.html

[2] Address of John Paul II. To members of the Pontifical Academy of Sciences. Saturday, 23 October 1982. http://w2.vatican.va/content/johnpaul-ii/en/speeches/1982/october/documents/hf_jpii_spe_19821023 pont-accademia-scienze.html

[3] Charter of the rights of the family, October 22, 1983, article 4C. http://www.vatican.va/roman_curia/ pontifical_councils/family/documents/rc_pc_family_ doc_19831022_family-rights_en.html

[4] Address of His Holiness Pope John Paul II at The Conclusion of the thirty-fifth General Assembly of the World Medical Association, Saturday, 29 October 1983. http://w2.vatican.va/content/johnpaul-ii/en/speeches/1983/october/documents/hf_jpii spe 19831029 ass-medica-mondiale.html

[5] Congregation for the doctrine of the faith. Instruction on respect for human life in its origin and on the dignity of procreation. Replies to certain questions of the

day. http://www.vatican.va/roman_curia/congregations/cf aith/ documents/rc_con_cfaith_doc_19870222_respectfor-human-life en.html

[6] Ioannes Paulus II Evangelium Vitae. To the Bishops, Priests and Deacons, Men and Women, religious lay, Faithful and all People of Good Will on the Value and Inviolability of Human Life. 25 March 1995. http://w2.vatican.va/content/john-paul-

ii/en/encyclicals/documents/hf_jp-

ii_enc_25031995_evangelium-vitae.html (доступ $2 \overline{2} .11 . \overline{2} 017)$,

http://www.unavoce.ru/library/evangelium vitae.htm $\underline{1}$

[7] Concluding Document of IV Plenary Assembly of the Pontifical Academy for Life «The Human Genome: Human Personhood and Future Society», $\begin{array}{lllll}\text { February } & 23 & - & 25 & 1998 .\end{array}$ http://www.vatican.va/roman_curia/pontifical_acade mies/

acdlife/documents/rc_pa_acdlife_doc_28091998_fin al-doc_en.html

[8] Congregation for the Doctrine of the Faith. Instruction Dignitas Personae on certain bioethical

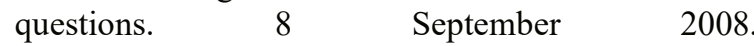
https://web.archive.org/web/20130118060111/http:// www.vatican.va/roman_curia/congregations/cfaith/ documents/rc_con_cfaith_doc_20081208_dignitaspersonae en.html

[9] Charter for Health Care Workers. Pontifical Council for Pastoral Assistance to Health Care Workers. Translated by The National Catholic Bioethics Center. Philadelphia. 2017.

[10] Pope John Paul II. Vitae Mysterium. Apostolic letter "Motu proprio" establishing the Pontifical Academy for

Life. http://www.academiavita.org/about_us_motu_propri o.php\#panel2

[11] Encyclical letter LAUDATO SI' of the Holy Father Francis on care for our common home. http://www.vatican.va/content/francesco/en/encyclic als/documents/papa-francesco_20150524 enciclicalaudato-si.html

[12] $\overline{\text { Lexicon, Discussion Topics and Ambiguous Terms }}$ in the Field of Family, Life and Ethics, Pontifical Council for Family Affairs, ed. Franciscans M., 2009 (in Russian)

[13] ENCYCLICAL LETTER HUMANAE VITAE OF THE SUPREME PONTIFF PAUL VI. http://www.vatican.va/content/paulvi/en/encyclicals/documents/hf_pvi_enc_25071968 humanae-vitae.html

[14] Sgrechcha E., Tambon B. Bioethics. M.: Biblical Theological Institute of St. Andrew, 2002. - 434 p. (in Russian)

[15] Compendium of the Social Doctrine of the Church. http://www.vatican.va/roman_curia/pontifical_counc ils/justpeace/documents/rc pc justpeace doc 20060 526 compendio-dott-soc en.html

[16] Catechism of the Catholic Church § 1756. http://ccconline.ru/ (in Russian) 
[17] Social position of the Protestant churches in Russia. https://www.cef.ru/documents/docitem/article/13793 87 (in Russian)

[18] "Before I formed you in the womb...": A Guide to the Ethics of Reproductive Medicine from the Council of the Community of Protestant Churches in Europe (CPCE, 2017). https://www.theologyethics.com/2017/08/04/beforei-formed-you-in-the-womb-a-guide-to-the-ethics-ofreproductive-medicine-from-the-council-of-thecommunity-of-protestant-churches-in-europe-cpce/

[19] Gilbert C. Meilaender, "Statement of Professor Meilaender," in President's Council on Bioethics, Human Cloning and Human Dignity: An Ethical Inquiry (Washington, DC: President's Council on Bioethics, 2002). https://bioethicsarchive. georgetown.edu/pcbe/reports/cloningreport/

[20] Table of Christian Population as Percentages of Total Population by Country. Pew Research Center. https://www.pewforum.org/2011/12/19/tablechristian-population-as-percentages-of-totalpopulation-by-country/

[21] Attitude towards religions. https://www.levada.ru/2018/01/23/otnoshenie-kreligiyam (in Russian)

[22] The Basis of the Social Concept of the Russian Orthodox Church. Ch. XII.6. Problems of Bioethics, 13-16 August 2000, Moscow. http://www.patriarchia.ru/db/text/419128.html (in Russian)

[23] Orthodoxy and problems of bioethics. Collection of works / Executive editor I.V. Siluyanova - Moscow: 2020 . - 172 p. (in Russian)

[24] Moral and Ethical Issues in Human Genome Editing. https://www.globethics.net/documents/4289936/181 92155/GE_CEC Flash_3 isbn9782889312948.pdf

[25] Chernov A.S. The phenomenon of Russian counterculture on the example of the national selfconsciousness of spiritual Christians-Molokans // Vestnik TSU. Issue 9 (89). 2010, pp. 229-233. (in Russian)

[26] From personal correspondence of E.E. Gribkov with the Presbyter of the community of Spiritual Christians, Molokans from the village of Slobodka, Tula Region, V.V. Tikunov (4.07.2020) (in Russian)

[27] TSIHSPD. Fundamentals of the Gospel. Salt Lake City, Utah, USA, 2009; TSIHSPD. Certain provisions of church policy and guidelines. https://www.churchofjesuschrist.org/study/manual/h andbook-2-administering-the-church/selected-

church-policies-and-guidelines/selected-churchpolicies?lang=rus (in Russian)

[28] Awake! "Infertility. New approaches, new questions". 2004. (in Russian)

[29] Awake! "Stem cells. Where is the line of what is permitted? " 2002. (in Russian)

[30] Aristotle. In: History of Animals, Books VII-X. 3. Balm DM, editor. Vol. 7. London: Loeb Classical Library; 1991.

[31]SYRIAN ORTHODOX PATRIARCHATE. https://web.archive.org/web/20111114165722/http:// syrian-orthodox.com/article.php?id=48
[32]L'embryon: formation et animation. Antiquité grecque et latine, traditions hèbraïque, chrétienne et islamique

\section{About the authors}

Gribkov Edward E. student of National Research Tomsk State University, E-mail: astratys@gmail.com

Minchenko Tatiana P., Professor of Tomsk State Pedagogical University, E-mail: mtp70@mail.ru 